\title{
0852. Selective decontamination of the digestive tract modulates the metabolic profile in a ventilator-induced lung injury model
}

\author{
Y Rojas ${ }^{1,2}, \mathrm{~S} \mathrm{Naz}^{3}$, JL Izquierdo ${ }^{4}$, N Nin ${ }^{5,6}$, A Ferruelo ${ }^{1,2}$, P García-Hierro ${ }^{7}$, D Molina-Arana ${ }^{7}$, R Herrero $^{1,2}$, \\ L Martínez-Caro ${ }^{1,2}$, A García $^{3}$, MA de la Cal ${ }^{1,2}$, JM Ruiz-Cabello ${ }^{4}$, C Barbas $^{3}$, JA Lorente ${ }^{1,2,8^{*}}$
}

From ESICM LIVES 2014

Barcelona, Spain. 27 September - 1 October 2014

\section{Introduction}

Acute lung injury induced by mechanical ventilation [ventilator-induced lung injury (VILI)] is characterized by a particular metabolic profile in the lung and in the systemic compartment [1]. Also, VILI has been associated with an increase in intestinal permeability [2]. We hypothesized that selective decontamination of the digestive tract (SDD) can modulate the metabolic profile associated with mechanical ventilation.

\section{Objectives}

To determine (1) the metabolic profile associated with VILI to identify potential biomarkers; (2) whether SDD modifies this metabolic profile associated with VILI.

\section{Methods}

Rats were pretreated with antibiotics by oral gavage for SDD (polymyxin E $30 \mathrm{mg} / \mathrm{ml}$, tobramycin $12 \mathrm{mg} / \mathrm{ml}$ ) or vehicle (water) as control. Twenty four hours later, rats were ventilated for $2.5 \mathrm{~h}$. VILI was induced by using high tidal volume $\left(\mathrm{V}_{\mathrm{T}}=25 \mathrm{ml} / \mathrm{kg}\right)+\mathrm{PEEP}=0 \mathrm{~cm} \mathrm{H}_{2} \mathrm{O}$. As control, rats were ventilated with low $\mathrm{V}_{\mathrm{T}}(9 \mathrm{ml} / \mathrm{kg})+\mathrm{PEEP}=$ $5 \mathrm{~cm} \mathrm{H}_{2} \mathrm{O}$. We studied four groups: Low $\mathrm{V}_{\mathrm{T}}-\mathrm{SDD}$, High $\mathrm{V}_{\mathrm{T}}$-SDD, Low $\mathrm{V}_{\mathrm{T}}$-vehicle and High $\mathrm{V}_{\mathrm{T}}$-vehicle $(\mathrm{n}=20$ per group). Lung tissue and serum were analyzed by ${ }^{1} \mathrm{H}$-nuclear magnetic resonance spectroscopy (H-MRS) and high pressure liquid chromatography coupled to quadruple time-of-flight (LC-MS-QTOF), respectively. Principal component (PCA) [unsupervisated] and partial least squares (PLS) [supervised] analyses were performed. Accurate masses of features representing significant

${ }^{1}$ Centro de Investigación Biomédica en Red de Enfermedades RespiratoriaS (CIBERES), Getafe, Spain

Full list of author information is available at the end of the article differences were searched against the MELTING, KEGG, LIPIDMAPDS and HMDB databases. We followed the Principles of Laboratory Animal Care (2010/63/UE 22-09, RD 53/2013 BOE 1-02, ley 32/2007 BOE 7-11).

\section{Results}

We found different metabolic patterns between rats ventilated with low and high $\mathrm{V}_{\mathrm{T}}$, and also between ventilated rats with and without SDD. In the lung, the main metabolic pathways affected are involved in energy metabolism (creatine, glucose, lactate, alanine, glutamate), protein synthesis (leucine) and membrane lipids (choline, phosphoethanolamine). In serum, the main affected pathways were related to conjugated bile acids, ceramide, Land's cycle and carnitine biosynthesis.

\section{Conclusions}

(1) Mechanical ventilation can change the metabolic profile in the lung and in the systemic compartment. (2) SDD can modify this metabolic changes induced by mechanical ventilation. (3) Metabolic studies can be useful to identify biomarkers for the diagnosis of acute lung injury, and to design new therapeutic strategies.

\section{Grant acknowledgment \\ FIS 12/02898, FIS 11/02791, FIS 12/02451, European Network (7th FP) ITN 264864, CA11/00260}

\section{Authors' details}

'Centro de Investigación Biomédica en Red de Enfermedades RespiratoriaS (CIBERES), Getafe, Spain. ${ }^{2}$ Hospital Universitario de Getafe, Intensive Care Service and Burn Unit, Getafe, Spain. ${ }^{3}$ Facultad de Farmacia, Universidad CEU San Pablo, Centro de Metabolómica y Bioanálisis (CEMBIO), Madrid, Spain. ${ }^{4}$ Centro de Investigaciónes Cardiovasculares (CNIC), Madrid, Spain. ${ }^{5}$ Hospital de Torrejon, Intensive Care Service, Madrid, Spain. ${ }^{6}$ Hospital Español, 
Intensive Care Service, Montevideo, Uruguay. ${ }^{7}$ Hospital Universitario de Getafe, Getafe, Spain. ${ }^{8}$ Universidad Europea de Madrid, Madrid, Spain.

Published: 26 September 2014

\section{References}

1. Izquierdo-Garcia JL, et al: A Metabolomic Approach to the Pathogenesis of Ventilator-induced Lung Injury. Anesthesiology 2014, 120(3):694-702.

2. Guery $\mathrm{BP}$, et al: Ventilation-induced lung injury is associated with an increase in gut permeability. Shock 2003, 19(6):559-63.

doi:10.1186/2197-425X-2-S1-P61

Cite this article as: Rojas et al:: 0852. Selective decontamination of the digestive tract modulates the metabolic profile in a ventilator-induced lung injury model. Intensive Care Medicine Experimental 2014 2(Suppl 1):P61.

\section{Submit your manuscript to a SpringerOpen ${ }^{\mathcal{O}}$ journal and benefit from:}

- Convenient online submission

- Rigorous peer review

- Immediate publication on acceptance

- Open access: articles freely available online

- High visibility within the field

- Retaining the copyright to your article

Submit your next manuscript at $\gg$ springeropen.com 